\title{
Building Research Framework of Relationship Between Corporate Culture, Working Motivation and Employee's Loyalty
}

\author{
Bui Thi Minh Thu ${ }^{1, *}$, Le Nguyen Doan Khoi ${ }^{2}$ \\ ${ }^{1}$ Hanoi University of Home Affairs in Central, Quang Nam, Viet Nam \\ ${ }^{2}$ Research Affairs Department - Technology Business Incubation Center, Can Tho University, Can Tho, Vietnam \\ Email address: \\ thubtm.gv@topica.edu.vn (B. T. M. Thu),lndkhoi@ctu.edu.vn (L. N. D. Khoi) \\ *Corresponding author
}

\section{To cite this article:}

Bui Thi Minh Thu, Le Nguyen Doan Khoi. Building Research Framework of Relationship Between Corporate Culture, Working Motivation and Employee's Loyalty. Science Journal of Business and Management. Vol. 4, No. 5, 2016, pp. 144-149. doi: 10.11648/j.sjbm.20160405.11

Received: July 24, 2016; Accepted: August 1, 2016; Published: August 21, 2016

\begin{abstract}
Corporate culture currently has played very important role of creating intangible asset for determining a sustainable development of firms. Researches on corporate culture in the world have been grouped into two main directions: firstly focusing on managerial characteristics of cultural factor in business management. Second one emphasizes impact of cultural factors on employees of firms, especially firms with multi-culture environment. This paper follows the second direction, which studies effect of cultural factors on working motivation, and employee's loyalty. Objective of this study is to build a research framework of relationship between corporate culture, working motivation and employee's loyalty, applying for Vietnamese enterprises.
\end{abstract}

Keywords: Working Motivation, Loyalty, Corporate Culture

\section{Introduction}

Corporate culture currently has been considered as a part of social capital creating intangible asset for determining a sustainable development of firms. Thus, building corporate building plays an important role in making competitive advantage of firms, boosting working motivation and loyalty of employees [1]. It is even more essential to research deeply on the working motivation, loyalty, their stimulating factors in tough working environment [2]. The corporate culture can push up innovation in firms, productivity and motivation for employees [3].

If mangers could build appropriate corporate culture, the culture will help in improving the firm's performance [4]. Moreover, other researchers conclude that corporate culture is the key to enhance firm's performance, boost working motivation [5]. Corporate culture also results in employe's satisfaction and higher working motivation.

Corporate culture is of great significance in maintaining loyaly of employees. Many researches have pointed out that corporate culture enhances employee's loyalty and keep them working for the organization in long term [6]. Employee's loyalty and commitment are the key to success of any firm [7].

There are a number of researches in Vietnam studying the relationship between corporate culture and working motivation, or between influences of corporate culture on loyalty. The research at FPT company's Information System (FPT IS) in Vietnam studied how corporate culture affects employees' commitment to the company. The result showed that there are 7 factors of corporate culture relate postitively to commitment [8].

Researches in Vietnam and in the world have focused on three directions: corporate culture's impact on working motivation; corporate culture's impact on employee's loyalty; and the relationship between working motivation and employee's loyalty.

There is no previous research that investigates the multilateral relationship between corporate culture, working motivation and employee's loyalty. Moreover, the eastern culture put high emphasis on employee's loyalty and managers try to find ways to motivate their inferior.

This paper concentrates on the relationship: building employee's loyalty, improving working motivation through corporate culture. The author use scales by Denison to measure corporate culture, working motivation and employee's loyalty to evaluate the degree to which corporate culture affects working motivation [9]. Currently, there is no previous research studying the mentioned relationship in Vietnam. 


\section{Literature Review and Research Framework}

\subsection{Definitions}

\subsubsection{Corporate Culture}

According to Hofstede, corporate culture (CC) has become an academic issue in the United States from 1979 and appeared frequently in those years [10]. Hofstede defines CO as the value system that is commonly accepted and widely announced, in a certain group, at a certain time. Currently, CC has become a controversial concept, both in theory and in reality. It continued expanding in different aspects because new defitinions have come out continuously.

Schein has synthesized factors to describe corporate culture, including behavior patterns, group standards, shared values, norms, rules, atmosphere, inherited skills and morals, typical metaphor or assumptions, symbols and festivals [11]. Denison argues that culture refers to the underlying values, beliefs and principles that serve as a foundation for an organisation's management system as well as the set of management practices and behaviors that both exemplify and reinforce those basic principles [12]. Gordan and Ditomaso give a definition of corporate culture emphasizing on a pattern of shared and stable beliefs and values that are developed within the company over time [13].

Based on the above mentioned definition of culture and empirical researches, culture in this paper can be defined: Corporate culture is a soul part of firm, creating distinctive characteristic for firm and be able to make difference with others. Corporate culture is product of all employees and adapts need of a sustainable value. Corporate culture makes a common belief, working motivation, improvement of loyalty, pushing up employees to gather for an overall objective of firm.

\subsubsection{Working Motivation}

Van Niekerk regarded motivation at workplace as created by the workplace environment and conditions that exert an influence on workers to perform some kind of activity by their own wish. According to him, workers want to reach some specific goals to have an inner satisfaction and to satisfy their own needs [14]. Pinder gave his idea by keeping in mind the work place of organizations. He explained work motivation as a set of internal and external forces that help in initiating behaviours that are work related [15]. According to the definition of Pinder, work motivation has features that are invisible, and they are created from a person's inner self and that researchers therefore must rely on the theories that are already established in order to have some guidance in measuring work motivation.

For the purpose of this particular study, employee motivation is taken as an instinctive force, that is maintained and shaped by a set of personal characteristics as well as workforce characteristics, that depend on the particular needs and motives of the workers.

As it is already mentioned above, the concept of motivation is of very high importance with regard to the effectiveness of an organization, as many researches show that motivation creates a link between job satisfaction and job performance of the employees, and job performance is the determinant of profitability and success of the organization. So, in order to make their employees optimally motivated, it is necessary for an organization to focus on the factors in job content that result in employee motivation and job satisfaction.

It is quite necessary for the managers and leaders to have a good knowledge about different motivational theories in order to have an effective management. Managers and leaders would need to choose the right theory to motivate a particular person in a particular situation and therefore have higher-performing and more satisfied employees.

Frederick Herzberg did not base on demand satisfaction, expectation or equality to develop motivation theory but the relationship between an individual and work and the attitude towards work, this relationship determine whether he/she succeeds or fails [16].

Herberzg supposed that there are internal factors (Motivators) and external factors (Maitaining factors) beside satisfaction and dissatisfaction, these factors relates to working motivation in the relationship between work and attitude. In the scope of this research, the author support view of Herzberg in "The motivation to work" which stated that motivation is the desire and willingness of employee to make progress to achieve organizational goals.

\subsubsection{Employee's Loyalty}

The definition of loyalty or commitment to organization has been explored by many researchers around the world $[17,18]$ in the field of human resource management, industry management/organizational psychology and behavior.

Employee loyalty (typically synonymous with commitment) to the organization has sometimes been viewed as an attitude. However, it is not so much an attitude (or thought component) that is important in organizations, but rather it is the bottom-line action component [19]. Employee loyalty is the willingness to remain with the organization [20]. Employee loyalty can be defined as employees being committed to the success of the organization and believing that working for this organization is their best option. Not only do they plan to remain with the organization, but they do not actively search for alternative employment and are not responsive to offers [21].

Mowday, Steers and Porter [18, p226] defined loyalty as intention or desire to be member of an organization. The famous definition of loyalty by Mowday is similar to the concept of "Maintain" in nation-wide research of Aon Consulting Institue: Employees with loyalty will stay even although they get higher paid job offer.

In this research, the author uses the definition of loyalty as: Loyalty employee is the one who understand and behave in accordance with organization's vision, mission and goals. They work with greatest effort and organizational goals are more important to them than their own benefits, they commit to the company in long term.

\subsection{The Relationship Between Corporate Culture, Working Motivation and Employee's Loyalty}

\subsubsection{Corporate Culture and Working Motivation}

Working motivation is the important factor relating to how people feel about their work, the level of determination, commitment and satisfaction. Research of Schneider và Synder has proved that there is an interdependent relationship 
between corporate culture and working motivation [22]. There are evidences from previous studies that motivation and employee's satisfaction depend on how the corporate culture align organizational goals [23]. Research of Wiscombe claimed that corporate culture with recognition and reward system generates working motivation [24]. According to Clarke, competitive environment for acquiring talents makes keeping excellent employee stay essential for the development of firms, firms now recognize that they have to build a more attractive corporate culture to generate working motivation among their emplyees [25].

Emplyees with working motivation feel proud when they do their tasks and they also feel responsible for firm's success. This raised an issue among managers of how to motivate their inferiors [26]. According to Hofstede, recognized work done by employees motivate them work harder in the future [27]. Working motivation and corporate culture are linked together by 5 motives by Kanter, including inspiring tasks (make them believe what they do is important), controlling program (allow employee to manage their own work), part of value creation (employee make effort to success), learning (providing opportunity to learn), and reputation (offer employee to create their own reputation) [28]. This research was further developed by Denison and Truskie, which claimed that there was a strong tie between motivation and culture: strong motivation create strong working motivation [29, 30].

Hypothesis 1: Corporate culture is positively related to working motivation of employee

\subsubsection{The Relationship Between Corporate Culture and Employee's Loyalty}

Based on research model of Ricardo và Jolly, four dimensions of corporate culture including training and development, recognition and reward, teamwork, and organizational communication have different impact on employee's loyalty [31]. In the field of quality control [32, 33, 34], there was evidence that corporate culture increases loyalty of employees and enhances competive advantage of the organization. Kumar supposed that employee's loyalty related to factors of corporate culture such as: (a) Organizations provide employees with training program to help improve skills and broaden knowledge; (b) open communication between leaders and employees; (c) encourage teamwork; (d) effective internal communication [35]. With such arguments, the author developed the hypothesis: strong corporate culture is postitively related to employee's loyalty.

Hypothesis 2: Corporate culture is postitively related to employee's loyalty

\subsubsection{The Relationship Between Working Motivation and Employee's Loyalty}

Many academics in the field of motivation supposed that there is a strong connection between working motivation and employee's loyalty [36, 37, 38]. The research of Adeyinka Tella, CO Ayeni and SO Popoola (2007) about the relationship between working motivation and employee's loyalty in libraries indicates that there is mutual relationship between motivation and loyalty: the higher the motivation, the stronger the loyalty [39].

Hypothesis 3: Working motivation has positive impact on employee's loyalty

\subsection{Proposed Research Model}

Literature review has showed that working motivation is very important to firm's performance because it builds strong tie between employee's satisfaction and work performance, therefore increasing profit and sucesss for firms. One of the factors contributing largely to creating working motivation is corporate culture. When the employee has working motivation, they are more loyal to firms and vice versa. On the other hand, all the mentioned models of corporate culture showed that assumption or values are the core determinant of how corporate culture influence working motivation and employee's loyalty. This determinant is hard to be recognized or observed, only explored through analyzing and evaluating awareness and behavior of organizational member. From that analysis, solutions or suggestions for corporate culture are developed. The below figure is research model proposed by authors (Figure 1).

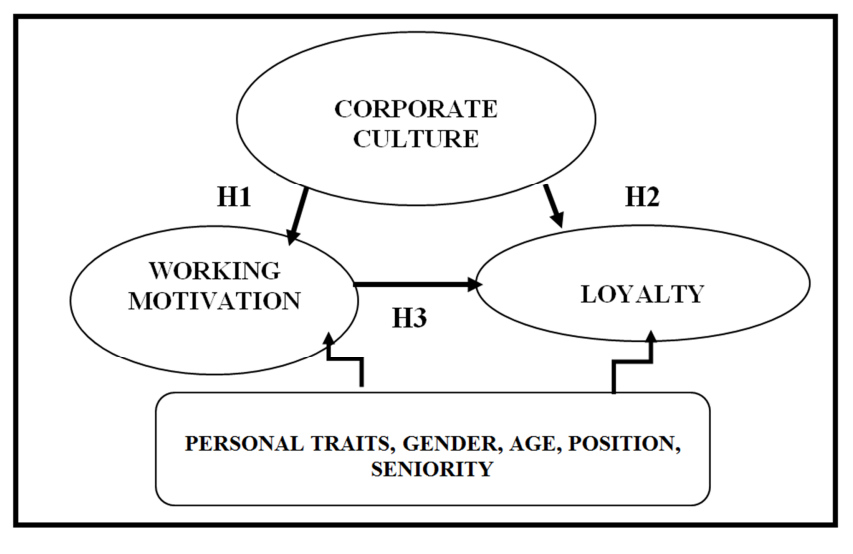

Source: outlined by authors

Figure 1. Proposed research model.

\section{Proposed Research Methodology}

Although the framework is conceptual, it derives from a lot of previous empirical studies. In its turn, it is expected to deal with/apply in practical cases at more comprehensive and integrated scope. This section will try to provide solutions to operationalize the conceptual framework in reality, or test it empirically. These solutions are related to variables indicating constructs in the framework, measurement of variables and analytical methodology. It should be perceived that these following solutions are illustrating examples rather than concrete guidance that can apply for all cases. The purpose of these solutions is to support for possible studies in the future.

About the methods of gaining data for the empirical research, a survey by questionnaire should be conducted in certain time and area. A structured questionnaire should be administered to the directors of firms in the area. Prior to the launch of the official questionnaires, a pilot test of the questionnaire should be conducted so that some possible modifications may be taken.

For variables indicating constructs of the framework, firstly, in this research, the author used the model by Denison to measure corporate culture for the following reasons [9]:

- This model provides scales and criteria to evaluate the 
strength of corporate culture with 4 items (adaptability, mission, consistency, and involvement); each item has 3 expressions and 2 dimensions: internal focus and external focus, Flexible and Stable.

- This model has questionnaire designed based on coporate behavior and environment with the aim to exploit both behavior and belief rather than general emotions. This model has been adapted by 5000 enterprises and academics around the world during past 20 years. It could be concluded that this model is reliable in measuring corporate culture.

The Denision model answered 4 questions:

1. Do the organization have clear view about direction of development? The result will reflect the awareness of members about long tern plan, or mission, which includes: (i) Strategic Direction and Intent; (ii) Goals and Objectives; (iii) Vision.

2. Do the organization understand the market and customers to behave appropriately? The result will reflect the appreciation of corporate culture through effectiveness of process and systems, also called integration, including: (i) Coordination and Integration; (ii) Agreement; (iii) Core values.

3. Do organization have system to enforce direction and intent effectively? The result will reflect the ability to build capability and responsibility of employee, also called involvement, including: (i) Empowerment; (ii) Team Orientation; (iii) Capability Development.

4. Do the employee commit to the planned targets and goals? The result will reflect the ability of firm to convert customer's need into business activities, also called as adaptability, including: (i) Organizational Learning; (ii) Customer Focus; and (iii) Creating Change.

Denision model brings users clear advantages in evaluating corporate culture:

(1) Attain baseline assessment of current cultural strengths and weaknesses.

(2) Allow the determination of which content or scope of culture need improvements.

(3) Align leadership direction with corporate culture.

Therefore, the author used Dainel Denison [9] to design the questionnaire for investigating the proposed development intent to give evaluation about success and limitations of corporate culture.

Secondly, research of Sjoberg và Lind proposed a scale to measure working motivation which includes 12 items and has been widely applied in the industry and service [40]. Based on this research as well as other previous studies [41, 42], the author developed a following scale for measuring working motivation:

Table 1. Measurement of working motivation.

\begin{tabular}{ll}
\hline Items & Explaination \\
\hline DLLV1 & I am motivated by work \\
DLLV2 & I am motivated by job tasks and assigment \\
DLLV3 & $\begin{array}{l}\text { I would like my family members and relatives choose the } \\
\text { similar job }\end{array}$ \\
DLLV4 & I am always in good mood at work \\
DLLV5 & I highly apreciate the reward system \\
DLLV6 & I want to spend more time for work \\
DLLV7 & I am willing to vring work home \\
DLLV8 & I am willing to work at lunch time \\
DLLV9 & I am eager to come back to work after holiday \\
\hline
\end{tabular}

Source: Authors
Thirdy, loyalty is a principle concept, measured by observing items. Loyalty scale by Aon Consulting [43; p8pp10-11] supposed that loyalty could be measured by the following items:

- Employees intend to work for company in a long term

- Employees will stay even though they receive better job offer

- Employees consider company as second home

Loyalty scale by Man Power, items to measure employee's loyalty include [44, p11-p19]:

- Willingness to recommend company as a good working environment

- Willingness to recommend company's products and services

- Intention to work in a long term

In research of Tran Kim Dung in Vietnam, she used the modified loyalty scale of Aon Consulting (revised and credibility proven in reality) [45]. Therefore, in this research, the author used this modified scale to measure loyalty, which includes:

- LTT1. Employee intends to work for company in a long term

- LTT2. Employee considers company as second home

- LTT3. Employee is willing to protect company's reputation and assets.

- LTT4. Employee will stay even though they receive better job offer

In terms of analytical methodology, this framework is proper to be tested empirically with a large enough sample of firms in one industry. The sample is also representative for the industry. The framework shows dependent relationships between constructs in an integrated mode, so it is the best if the framework utilizes structural equation modeling (SEM) to analyze. With this kind of methodology, all relationships of the framework will be revealed by only one graphic integrated as the conceptual framework. However, if this methodology is impossible due to nature of data or limited size of sample, method of separate regressions will be more feasible. In addition, in order to analyze these models, statistical software packages such as SPSS, AMOS and STATA can be used to be suitable for each situation.

\section{Conclusion}

This paper is to build the 3-dimension relationship that is new and eastern approach: inspiring employee's loyalty and enhancing working motivation by building appropriate corporate culture. After reviewing literature related to all these relationships, an integrated framework was proposed. In general, this paper is expected to make several contributions to mostly academics. This research has developed a new research framework to study the relationship between corporate culture, working motivation and employee's loyalty. Currently in Vietnam, there are rarely studies about this relationship.

However, like almost all researches, this paper also faces some limitations. The first one is scope of applicability of the framework. This framework is assumed to apply for analyzing firms in one industry, but not firms in mixed industries. One industry will give a common background and decrease complicated factors among industries. The second one is that 
the framework is not instant applicability. Any researcher who wants to apply the framework needs to review literature thoroughly to adapt to each situation. For the future studies, this framework is really needed to test empirically in different environment (industry, country, economies). By doing that, the framework can prove its applicability and be further improved. This research paper aims at proposing a comprehensive integrated framework from all literature review. It is not a simple combination among three factors; it is expected to propose a framework integrated at a proper mechanism.

\section{References}

[1] Noe, R. (2013). Employee Training and Development, 6th Edition, McGraw Hill.

[2] Bard, M. \& Moore, E. (2000). Mentoring and self - managed learning: professional development of the market research industry, International Journal of Market Research, Vol. 42 No. 3, pp. 255-75.

[3] Calorie, R., \& Sarini. (1991). Corporate Culture and Economic Performance. Organization Studies, 12, 49-74.

[4] Ashkanasy, N., Wilderon, C., Peterson, M. F. (2000). Handbook of Organizational Culture and Climate. Thousand Oaks, CA.

[5] Wanda Roos (2005). The relationship between motivation and satisfaction of employees with corporate culture, University of South Africa, USA.

[6] Takada \& Westbrook (2009). The impact of organization Culture on satisfaction on engineers in Technology University of Alabama in Huntsville 2009. [cit. 2009-02-27]

[7] Shahid, A., \& Azhar, SM (2013). Gaining employee commitment: Linking to organizational effectiveness. Journal of Management Research, 5 (1), 250-268.

[8] Truong Hoang Lam \& Đo Thi Thanh Vinh (2012). Impact of cultural factors on commitment of employees: Case study of FPT company, Conference Proceedings "Management and Business in 2012" in Danang city.

[9] Denison Consulting. (2011). Overview of the Reliability and Validity of the Denison Organizational Culture Survey.

[10] Hofstede, G. (2001). Culture's Consequences - Second Edition: Comparing Values, Behaviors, Institutions and Organizations Across Nations. London: Sage.

[11] Schein, E. M. (2004). Organizational culture and leadership. (3rd. ed.). Jossy-Bass.

[12] Denison, D. R. \& A. K. Mishra (1995). Toward a Theory of Organizational Culture and Effectiveness, Organization Science, 6 (2), 204-223.

[13] Gordon, G., \& Ditomaso, N., (1992). Predicting Corporate Performances given Organisational Culture, Journal of Management Studies, 29(1), 783-798.

[14] Van Niekerk, W. P. (1987). Eietydse bestuur (Contemporary management). Durban: Butterworth.

[15] Craig C. Pinder (1998). Work Motivation in Organizational Behavior, Prentice Hall.

[16] Herzberg, F. (1966). Work and the nature of man. Cleveland, $\mathrm{OH}$ : World Publishing Company.
[17] Mowday, R., Steers, R., \& Porter, L. (1979). The measurement of organizational commitment, Journal of Vocational Behavior, 14, 224-247.

[18] Porter, L., Steers, R., Mowday, R. \& Boulian, P. (1974). Organizational commitment, job satisfaction and turnover among psychiatric technicians, Journal of Applied Psychology, 59, 603-609.

[19] Meyer, J. P., \& Allen, N. J. (1991). A three-component conceptualization of organizational commitment. Human Resource Management Review, 1, 61-89.

[20] Solomon, C. M. (1992). The loyalty factor, Personnel Journal, 52-62.

[21] The Loyalty Research Center: 317-465-1990, www.loyaltyresearch, pp 1-5.

[22] Schneider, B. \& Snyder, R.A. (1975). Some relationship between job satisfaction and organizational climate. Journal of Applied Psychology, 60(3), 318-328.

[23] Sempane, M. E., Rieger, H. S. \& Roodt, G. (2002). Job satisfaction in relation to organisational culture. South African Journal of Industrial Psychology, 28(2), 23-30.

[24] Wiscombe, J. (2002). Rewards get results. Workforce, 81(4), 42-47.

[25] Clarke, R. D. (2001). Well dones" shouldn't be rare, Black Enterprise, 32(3), 67-69

[26] Du Toit, M. A. (1990). Motivering (Motivation). In J. Kroon (Ed.), Algemene bestuur (General management) (2nd ed.) (pp. 83-92). Pretoria: HAUM.

[27] Hofstede, G. (2001). Culture's Consequences - Second Edition: Comparing Values, Behaviors, Institutions and Organizations Across Nations. London: Sage.

[28] Kanter, R. M. (1989). The new managerial work, Harvard Business Review, 67, 85-92.

[29] Denison, D. R. (1990). Corporate Culture and Organizational Effectiveness, New York: Wiley.

[30] Truskie, S. (1999). Leadership in High-performance Organizational Cultures. Quorom Books.

[31] Ricardo, R \& Jolly, J. (1997). Training of teams in the workplace. S. A. M Advanced Management Journal, 62(2).

[32] Acton, T \& Golden, W. (2002). Training: The way to retain valuable IT employees. Conference proceedings, Informing Science, 1-12.

[33] Karia, N. (1999). The impact of TQM practices on employees' work related attitude. MBA Unpublished Research Report, Universiti Sains Malaysia.

[34] Karia, N \& Ahmad, Z. A (2000). Quality practices that pay: Empowerment and teamwork. Malaysian Management Review, 35(2), 66-76.

[35] Kumar, V., \& Shah, D. (2004). Building and sustaining profitable customer loyalty for the 21 st century. Journals of Retailing, 80, 317-330.

[36] Basset-Jones, N. \& Lloyd, G.C. (2005). Does Herzbergs Motivational Theory have staying power? Journal of Management Development, 24 (10), 57-56.

[37] Chen, P. T., \& Hu, H. H. (2010). The effect of relational benefits on perceived value in relation to customer loyalty: An empirical study in the Australian coffee outlets industry. International journal of hospitality management, 29, 405-412. 
[38] Lok, P. \& Crawford, J. (2001). Antecedents of organizational commitment and the mediating role of job satisfaction. Journal of Managerial Psychology, 16(8), $594-613$

[39] Adeyinka Tella., Ayeni, C.O., \& Popoola, S.O. (2007). Work Motivation, Job Satisfaction, and Organisational Commitment of Library Personnel in Academic and Research Libraries in Oyo State, Nigeria. Library Philosophy and Practice, 118.

[40] Sjoberg, L., \& Lind, F. (1994). Arbetsmotivation $i$ en krisekonomi: En studie av prognosfaktorer (Work motivation in financial crisis: A study of prognostic factors. Stockholm School of Economics, Department of Economic Psychology.

[41] Bui Thi Minh Thu, \& Le Nguyen Đoan Khoi. (2014). Factors contributing to working motivation of employees in Lilama Corporation in Vietnam. Can Tho University Journal, 67-68.
[42] Bui Thi Minh Thu, Le Nguyen Đoan Khoi. (2015). Factors affecting working motivation of employees in mechanical industries in Central part of Vietnam. Social Science Institute Journal, 38-41.

[43] Stump, E (2001). Augustine on free will. The Cambridge Companion to Augustine.

[44] Man Power inc (2002). Internationnal Loyalty Survey. Wiscosin USA.

[45] Tran Kim Dung, \& Nguyen Thi Mai Trang (2007). Impact of corporate culture and leadership style on performance of employees and their loyalty to organization, Research project, University of Economics, Hochiminh City. 